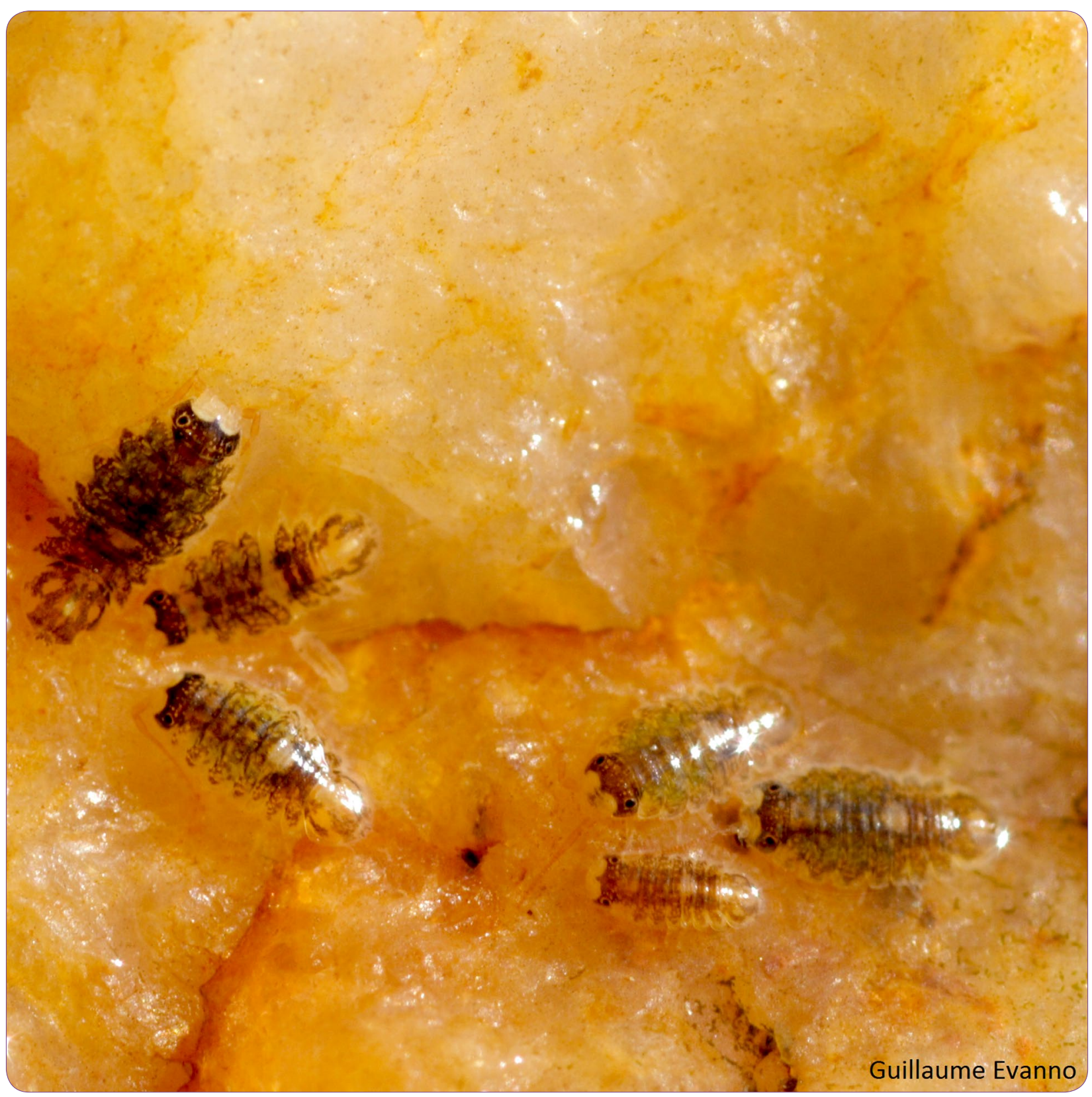

\title{
Microsatellite markers for the Jaera albifrons species complex (marine isopods)
}

Ribardière et al. 


\title{
Microsatellite markers for the Jaera albifrons species complex (marine isopods)
}

\author{
Ambre Ribardière* ${ }^{*}$ Thomas Broquet and Claire Daguin-Thiébaut
}

\begin{abstract}
Background: The Jaera albifrons complex contains five species of marine isopods (J. albifrons, J. praehirsuta, J. ischiosetosa, J. forsmani, and J. posthirsuta). These species, occurring on the shores of the North-Atlantic Ocean, are partially reproductively isolated by barriers due to sexual isolation (mate choice), genetic incompatibilities, and ecological specialization. Microsatellite loci would be useful for parentage-based analyses of sexual selection and studies of genetic structure in the context of speciation.

Findings: Twenty-four microsatellite markers were developed for J. albifrons using pyrosequencing of enriched libraries. Patterns of polymorphisms were analyzed in $49 \mathrm{~J}$. albifrons adult males sampled in two populations from Brittany (Western France). The average number of alleles per locus was $4.73 \pm 2.45$ and the average gene diversity was $0.55 \pm 0.23$. Most markers also successfully amplified in the three sibling species J. praehirsuta, J. ischiosetosa, and J. forsmani.
\end{abstract}

Conclusions: These polymorphic and cross-amplifiable markers will be useful for population genetics and parentage studies in the J albifrons complex.

Keywords: SSR, Species complex, Cross-amplification, 454 pyrosequencing, Multiplex PCR

\section{Findings}

\section{Background}

The Jaera albifrons complex (Leach, 1814) is composed of five intertidal isopod species $[1,2]$. Three species $(\mathrm{J}$. albifrons, J. praehirsuta, and J. ischiosetosa) have a large distribution along the coasts of the North-Atlantic Ocean from South-Spain and South-USA up to Baltic and Arctic regions, while the two other species are restricted either to the North-American East coast (J. posthirsuta) or the European coasts (J. forsmani). Interest in these species stems from the fact that gene flow is interrupted by several isolating barriers but hybridization can occur under particular circumstances. Isolating barriers include ecological isolation, sexual isolation, and genetic incompatibilities [3, 4]. Microsatellite loci will be useful for population genetic studies of the $J$. albifrons complex, and fine scale analyses requiring parentage assignment (e.g. for investigating mechanisms of sexual

\footnotetext{
*Correspondence: ambre.ribardiere@sb-roscoff.fr

CNRS, Station Biologique de Roscoff, Sorbonne Universités, UPMC Univ Paris 06, UMR 7144, Team Diversity and Connectivity of Coastal Marine
} Landscapes, 29680 Roscoff, France selection). Microsatellite markers were developed using two French J. albifrons populations and cross-amplification was tested for the three other species that are found in Europe $(J$. praehirsuta, J. ischiosetosa, and J. forsmani).

\section{Methods}

Total genomic DNA was isolated from seven J. albifrons individuals (three males and four females) using the Nucleospin ${ }^{\circledR}$ Tissue kit (Macherey-Nagel) and sent to Genoscreen (Lille, France) for microsatellite development. Libraries enriched for microsatellites were prepared according to Malausa et al. [5] and sequenced on a 454 GS-FLX Titanium pyrosequencer (Roche). Among 42,661 raw sequences, 2609 microsatellite motifs were detected using QDD v1 [6] with default parameters, yielding 168 potential primer pairs. Among them, 95 primer pairs maximizing the number of repeats were tested for amplification and polymorphism using a set of seven J. albifrons individuals. Nine loci were found to be monomorphic, 46 loci did not yield amplification products, and 16 gave uninterpretable amplification patterns. The remaining 24 promising loci included dinucleotide, trinucleotide and tetranucleotide repeat motifs (Table 1). 


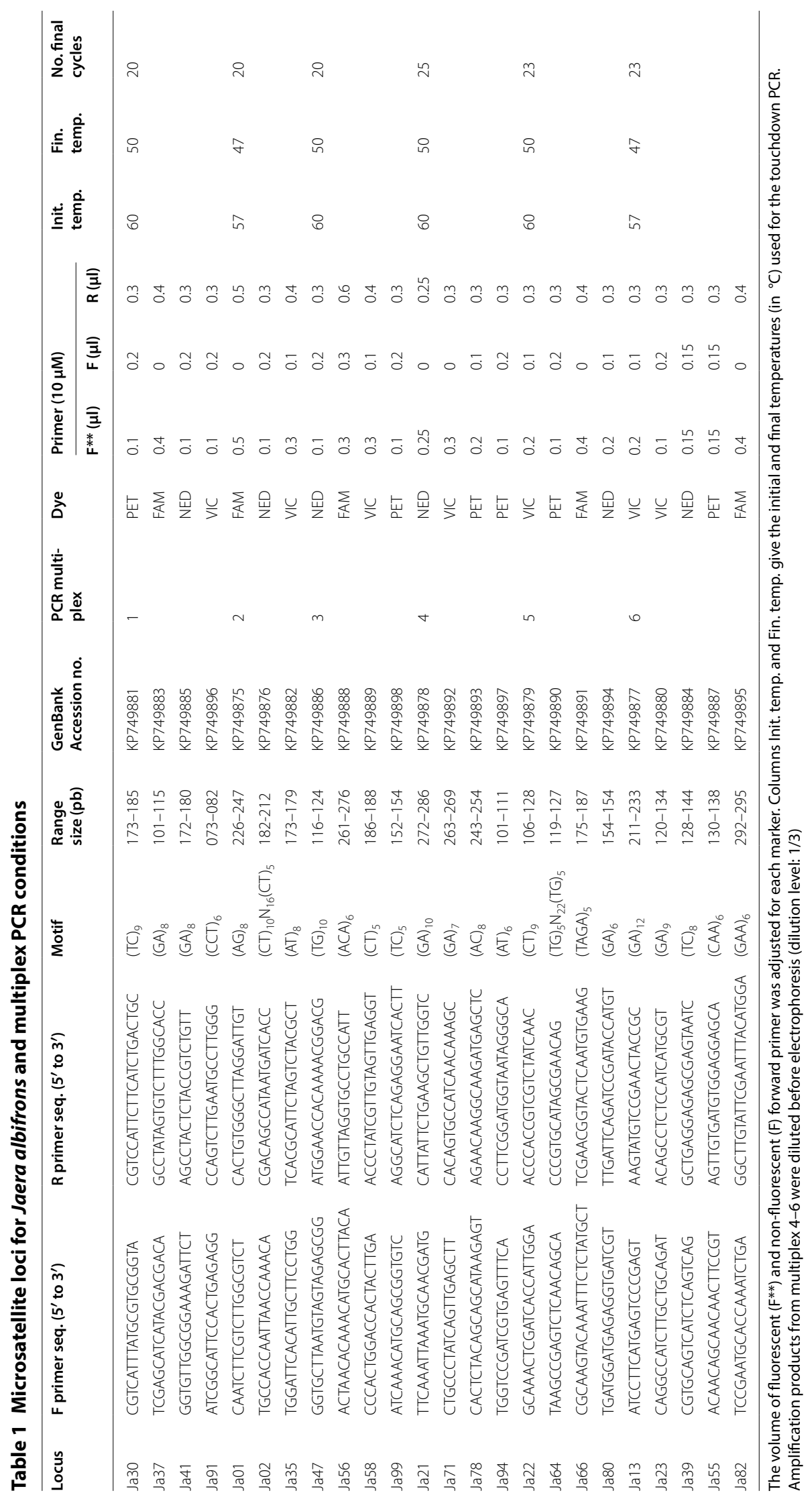


Polymorphisms of these 24 loci were estimated in two populations of $J$. albifrons from Brittany: Lingoz $\left(48^{\circ} 39^{\prime} 12.31^{\prime \prime} \mathrm{N}, 3^{\circ} 57^{\prime} 0.43^{\prime \prime} \mathrm{W}, n=24\right.$ males) and Inizan $\left(48^{\circ} 39^{\prime} 34.09^{\prime \prime} \mathrm{N}, 3^{\circ} 56^{\prime} 25.66^{\prime \prime} \mathrm{W}, n=25\right.$ males), for which genomic DNA was extracted from entire individuals using NucleoSpin ${ }^{\circledR} 96$ Tissue kit (Macherey-Nagel). Locus amplification was performed in six multiplex PCRs (three to five loci per PCR, Table 1), in $15 \mu$ l solutions containing $13 \mu \mathrm{l}$ of reaction mixture and $2 \mu \mathrm{l}$ of template DNA. Reaction mixtures contained $0.5 \mathrm{U}$ of Gotaq G2 Hotstart DNA polymerase (Promega), $1 \times$ PCR buffer, $0.25 \mathrm{mM}$ of each dNTP, $2 \mathrm{mM}$ of $\mathrm{MgCl}_{2}, 0.1 \mathrm{mg} / \mathrm{ml}$ of bovine serum albumin, and primers in locus-specific concentrations (Table 1). We used a touchdown PCR method, performed by a T100 Thermal Cycler (Bio-RAD) with the following conditions: initial denaturation at $95{ }^{\circ} \mathrm{C}$ for $4 \mathrm{~min}$, followed by ten cycles of $95^{\circ} \mathrm{C}$ for $30 \mathrm{~s}$, annealing for $30 \mathrm{~s}$ with temperature step-downs $\left(1{ }^{\circ} \mathrm{C}\right.$ at each cycle) starting at an initial temperature specific to each multiplex (Init. temp. in Table 1), and $72{ }^{\circ} \mathrm{C}$ for $30 \mathrm{~s}$.
This was followed by $20-25$ final cycles of $95^{\circ} \mathrm{C}$ for $30 \mathrm{~s}$, final temperature (Fin. temp.) for $30 \mathrm{~s}, 72^{\circ} \mathrm{C}$ for $30 \mathrm{~s}$, and a final elongation at $72{ }^{\circ} \mathrm{C}$ for $10 \mathrm{~min}$.

PCR products were electrophoresed in a ABI 3130XL capillary sequencer (Applied Biosystems) together with the SM594 size marker [7] and electropherograms were analyzed using Genemapper v4 (Applied Biosystems). The number of alleles per locus, allelic richness, and observed and expected heterozygosity were estimated in Fstat vs. 2.9.3.2 [8]. This software was also used to test for Hardy-Weinberg equilibrium (Global test, option "HW within samples", 10,000 permutations, Bonferroni correction applied), population differentiation, and linkage disequilibrium (option "between all pairs of loci in each sample", 11,040 permutations). The presence of null alleles was tested using Micro-Checker vs. 2.2.3 [9].

Finally, the transferability of these markers was tested on three other species from the J. albifrons complex: J. praehirsuta $(n=74$ males from five European

Table 2 Polymorphism of Jaera albifrons microsatellite loci

\begin{tabular}{|c|c|c|c|c|c|c|c|c|c|c|c|}
\hline \multirow[t]{2}{*}{ Locus } & \multicolumn{4}{|c|}{ Lingoz $(n=24)$} & \multicolumn{4}{|c|}{ Inizan $(n=25)$} & \multicolumn{3}{|c|}{ Cross-amplification (no. alleles) } \\
\hline & $\begin{array}{l}\text { No. } \\
\text { alleles }\end{array}$ & Ho & $\mathrm{He}$ & $\mathrm{F}_{\mathbf{I S}}$ & $\begin{array}{l}\text { No. } \\
\text { alleles }\end{array}$ & Ho & $\mathrm{He}$ & $\mathrm{F}_{\mathbf{I S}}$ & $\begin{array}{l}\text { J. praehirsuta } \\
(n=74)\end{array}$ & $\begin{array}{l}\text { J. ischiosetosa } \\
(n=18)\end{array}$ & $\begin{array}{l}\text { J. forsmani } \\
(n=8)\end{array}$ \\
\hline Ja30 & 4 & 0.63 & 0.64 & 0.031 & 6 & 0.72 & 0.71 & -0.013 & 7 & 5 & 6 \\
\hline Ja37 & 4 & 0.39 & 0.67 & 0.418 & 6 & 0.32 & 0.56 & 0.432 & $9^{\#}$ & $5^{\#}$ & 4 \\
\hline Ja41 & 4 & 0.46 & 0.45 & -0.016 & 5 & 0.56 & 0.50 & -0.113 & 10 & 8 & 5 \\
\hline Ja91 & 4 & 0.50 & 0.53 & 0.053 & 3 & 0.60 & 0.56 & -0.137 & 6 & 3 & 4 \\
\hline Ja01 & 9 & 0.43 & 0.85 & $0.496^{*}$ & 11 & 0.59 & 0.84 & 0.302 & 22 & $3^{\#}$ & $4^{\#}$ \\
\hline $\mathrm{Ja02}$ & 7 & 0.71 & 0.73 & 0.035 & 6 & 0.76 & 0.68 & -0.118 & 11 & 4 & 5 \\
\hline Ja35 & 5 & 0.54 & 0.58 & 0.074 & 4 & 0.64 & 0.66 & 0.035 & 7 & 2 & 4 \\
\hline Ja47 & 4 & 0.67 & 0.61 & -0.087 & 4 & 0.40 & 0.55 & 0.278 & 5 & 1 & 4 \\
\hline Ja56 & 6 & 0.67 & 0.62 & -0.071 & 4 & 0.28 & 0.35 & 0.200 & 8 & 4 & 3 \\
\hline Ja58 & 2 & 0.00 & 0.08 & 1.000 & 2 & 0.08 & 0.27 & 0.713 & 6 & 2 & 1 \\
\hline Ja99 & 2 & 0.38 & 0.31 & -0.211 & 2 & 0.36 & 0.35 & -0.029 & 3 & 2 & 2 \\
\hline Ja21 & 5 & 0.57 & 0.69 & 0.183 & 6 & 0.52 & 0.70 & 0.257 & 12 & 6 & 3 \\
\hline Ja71 & 4 & 0.68 & 0.76 & 0.101 & 5 & 0.72 & 0.71 & -0.013 & 12 & 9 & -\# \\
\hline Ja78 & 5 & 0.61 & 0.75 & 0.197 & 5 & 0.71 & 0.70 & -0.009 & 8 & $6^{\#}$ & $4^{\#}$ \\
\hline Ja94 & 5 & 0.63 & 0.68 & 0.078 & 5 & 0.56 & 0.70 & 0.198 & 9 & 5 & 5 \\
\hline $\mathrm{Ja} 22$ & 6 & 0.79 & 0.73 & -0.094 & 6 & 0.52 & 0.58 & 0.102 & 10 & 6 & 2 \\
\hline Ja64 & 2 & 0.04 & 0.31 & $0.869^{*}$ & 2 & 0.12 & 0.35 & 0.662 & 6 & 2 & 3 \\
\hline Ja66 & 3 & 0.25 & 0.29 & 0.140 & 2 & 0.16 & 0.15 & -0.067 & 5 & $1 \#$ & 1 \\
\hline Ja80 & 1 & NA & NA & NA & 1 & NA & NA & NA & 4 & 1 & 2 \\
\hline Ja13 & 9 & 0.54 & 0.71 & 0.240 & 8 & 0.40 & 0.60 & 0.332 & 16 & 8 & 10 \\
\hline Ja23 & 4 & 0.50 & 0.69 & 0.275 & 7 & 0.76 & 0.71 & -0.078 & 8 & 5 & 4 \\
\hline Ja39 & 8 & 0.92 & 0.85 & -0.077 & 12 & 0.88 & 0.89 & 0.008 & 15 & 2 & $5^{\#}$ \\
\hline Ja55 & 3 & 0.17 & 0.59 & $0.720^{*}$ & 5 & 0.48 & 0.67 & 0.289 & 9 & 3 & 4 \\
\hline Ja82 & 2 & 0.29 & 0.25 & -0.150 & 2 & 0.12 & 0.12 & -0.043 & 2 & 2 & 2 \\
\hline
\end{tabular}

The number of alleles, expected heterozygosity $(\mathrm{He})$, observed heterozygosity $(\mathrm{Ho})$ and $\mathrm{F}_{\mathrm{IS}}$ are given for each locus in two populations of the $J$. albifrons species ${ }^{*}$ indicates a significant deviation from HWE, $p<0.05$ ). The number of alleles obtained through cross-amplification is given for samples of $J$. praehirsuta, J. ischiosetosa, and J. forsmani (" indicates amplification success below $85 \%$, see text). Loci presented in the same order as in Table 1 
populations), $J$. ischiosetosa ( $n=18$ males from two North-American populations), and J. forsmani ( $n=8$ males from one European population).

\section{Results and discussion}

The average number of alleles per locus for the two pooled $J$. albifrons populations $(\mathrm{n}=49)$ was $4.73 \pm 2.45$ and the average gene diversity was $0.55 \pm 0.23$ (details per locus and population in Table 2). All loci were polymorphic (2-13 alleles per locus) except Ja80, which is nonetheless reported here because it was polymorphic in J. praehirsuta and $J$. forsmani (Table 2) and could thus be useful at least for these species. Microsatellites Ja01, Ja55, and Ja64 deviated significantly from HWE $(p<0.001$ in one of the two populations). Micro-checker results suggested that null alleles might be segregating at these loci as well as three additional markers associated with large $\mathrm{F}_{\text {IS }}$ values (Ja13, Ja27, and Ja58). Null alleles are often unavoidable in highly polymorphic species such as many marine invertebrates [10] and relevant microsatellite loci should be used only in analyses where their effect can be detected and corrected (e.g. parentage assignment). Moreover, the occurrence of null alleles is expected to be variable across geographic regions and species, so that the results reported here for two populations might not apply to other areas or species (our two samples came from nearby, albeit differentiated populations, $\left.\mathrm{F}_{\mathrm{ST}}=0.01, p<0.0001\right)$. Markers used in empirical studies should be chosen accordingly, and the multiplex design proposed here could be adapted. There was no linkage disequilibrium for any pair of loci.

Cross-species amplification was considered successful if more than $85 \%$ of the individuals tested produced a good quality genotype at the first attempt and without optimization. With this criterion, 23 out of 24 microsatellite markers successfully amplified in J. praehirsuta $(n=74), 20$ in J. ischiosetosa $(n=18)$ and 20 in J. forsmani $(n=8)$. These loci appeared to be polymorphic in nearly all cases (Table 2). These markers seem readily transferable to other species for European populations of J. praehirsuta and J. forsmani, and even to North-American populations in the case of $J$. ischiosetosa. The panel of microsatellites reported here thus provides a useful set of markers for parentage analyses and studies of the interspecific genetic structure within the J. albifrons complex.

\section{Availability of supporting data}

The sequences containing microsatellite motifs are available through the National Centre for Biotechnology Information under accession numbers KP749875 to KP749898 (http://www.ncbi.nlm.nih.gov/).

\section{Authors' contributions}

AR performed field sampling, final multiplex optimization, genotyping and data analysis. TB contributed to field sampling, designed the primers, and supervised the analysis and description of polymorphism for the final set of loci. CDT performed initial tests for amplification and polymorphism, and supervised final multiplex optimization and genotyping. All authors contributed to writing the manuscript. The authors read and approved the final manuscript.

\section{Acknowledgements}

We thank J. Coudret and C. Houbin for their help during sampling and species determination, and J. Jaquiéry, F. Viard and G. Yannic for discussions and comments. This work benefited from access to the Biogenouest genomic platform at Station Biologique de Roscoff, and was supported by the French Agence Nationale de la Recherche (grant ANR-13-JSV7-0001-01 to T.B.).

\section{Competing interests}

The authors declare that they have no competing interests.

Received: 11 May 2015 Accepted: 19 October 2015

Published online: 02 November 2015

\section{References}

1. Bocquet C. Evolution of a superspecies of marine isopods. Syst Zool. 1954;3(4):148-62.

2. Prunus $\mathrm{G}$. Etude de systématique des populations chez l'isopode Jaera (albifrons) albifrons Forsman. Arch Zool Exp Gen. 1968;109:643-702.

3. Mifsud DV. The genetic basis of speciation in the Jaera albifrons species group of intertidal isopods: PhD dissertation, University of Aberdeen; 2011.

4. Solignac M. Isolating mechanisms and modalities of speciation in the Jaera albifrons species complex (Crustacea, Isopoda). Syst Zool. 1981;30(4):387-405.

5. Malausa T, Gilles A, Meglecz E, Blanquart H, Duthoy S, Costedoat C, et al. High-throughput microsatellite isolation through 454 GS-FLX titanium pyrosequencing of enriched DNA libraries. Mol Ecol Resour. 2011;11(4):638-44.

6. Meglecz E, Costedoat C, Dubut V, Gilles A, Malausa T, Pech N, et al. QDD: a user-friendly program to select microsatellite markers and design primers from large sequencing projects. Bioinformatics. 2010;26(3):403-4.

7. Mauger S, Couceiro L, Valero M. A simple and cost-effective method to synthesize an internal size standard amenable to use with a 5-dye system. Prim Res Biotech. 2012;2:40-6.

8. Goudet J. FSTAT, a program to estimate and test gene diversities and fixation indices (version 2.9.3), updated from Goudet 1995. Available from http://www.unil.ch/izea/softwares/fstat.html. 2001.

9. van Oosterhout C, Hutchinson WF, Wills DP, Shipley P. Micro-checker: software for identifying and correcting genotyping errors in microsatellite data. Mol Ecol Notes. 2004;4:535-8.

10. Hare MP, Karl SA, Avise JC. Anonymous nuclear DNA markers in the American oyster and their implications for the heterozygote deficiency phenomenon in marine bivalves. Mol Biol Evol. 1996;13(2):334-45. 